\title{
GEOARKEOLOGI KARST SAROLANGUN, JAMBI
}

\author{
Geoarchaeology of Karts Sarolangun, Jambi \\ M. Fadhlan S. Intan \\ Pusat Penelitian Arkeologi Nasional \\ Jl. Raya Condet Pejaten, No. 4, Jakarta, Indonesia \\ geobugis@yahoo.co.id
}

Naskah diterima: 21/02/2018; direvisi: 31/03-14/05/2018; disetujui: 20/07/2018

Publikasi ejurnal: 31/07/2018

\begin{abstract}
Sarolangun Karst belongs to the Sarolangun Regency, preserving the cultural remains of the mesolithic period, which has not been too concerned by environmental researchers, especially geoarchaeology. This is the issue that covers general geological conditions. The purpose of this research is to mapping the surface geology in general as an effort to present geological information related to archeological site. The aim is to know the geomorphological, stratigraphic aspects of the archaeological sites. The research method is done through literature review, survey, field data analysis and interpretation. Environmental observations provide information on the landscape of the study area consisting of terrestrial morphology units, weak wavy morphology, strong corrugated morphology units, and karst morphology units. The rivers are dendritic and rectangular, along with the mature-old river, the Old River, Periodic/Permanent River and the Episodic/Intermittent River. The rocks of prehistoric cave compilers are limestones. The geologic structure is a fracture of the shear fault type. Exploration at Sarolangun Karst has listed 6 cave sites. From the classification of petrology, litik tools made of jasper, chert, basalt and andesite rocks. Rock as a raw material litik, found around caves in both the outcrop and boulder. For obsidian sources are located in Bukit Hulu Simpang and Bukit Legal Tinggi.
\end{abstract}

Keyword: geology, holocene, mesolithic, closed sites, lithic materials.

\begin{abstract}
Abstrak
Karst Sarolangun termasuk wilayah Kabupaten Sarolangun, menyimpan tinggalan budaya yang berasal dari masa mesolitik, yang selama ini belum terlalu diperhatikan oleh peneliti lingkungan, khususnya geoarkeologi. Hal inilah yang menjadi pokok permasalahan yang mencakup kondisi geologi secara umum. Adapun maksud penelitian ini adalah melakukan pemetaan geologi permukaan secara umum sebagai salah satu upaya menyajikan informasi geologi terkait dengan situs arkeologi. Tujuannya adalah untuk mengetahui aspek-aspek geomorfologi, stratigrafi di situs-situs arkeologi. Metode penelitian dilakukan melalui kajian pustaka, survei, analisis data lapangan dan interpretasi. Pengamatan lingkungan memberikan informasi tentang bentang alam daerah penelitian yang terdiri dari satuan morfologi dataran, satuan morfologi bergelombang lemah, satuan morfologi bergelombang kuat, dan satuan morfologi karst. Sungainya berpola aliran dendritik dan rektangular, berstadia Sungai DewasaTua, Sungai Tua, Sungai Periodik/Permanen, dan Sungai Episodik/Intermittent. Batuan penyusun gua prasejarah adalah batugamping. Struktur geologi berupa patahan dari jenis patahan geser. Eksplorasi di Karst Sarolangun telah mendata 6 situs gua. Dari klasifikasi petrologi, alat-alat litik terbuat dari batuan jasper, chert, basal dan andesit. Batuan sebagai bahan baku alat litik, banyak ditemukan di sekitar guagua baik dalam bentuk singkapan maupun boulder. Untuk sumber obsidian terdapat di Bukit Hulu Simpang dan Bukit Legal Tinggi.
\end{abstract}

Kata Kunci: geologi, holosen, mesolitik, situs tertutup, bahan alat litik.

\section{PENDAHULUAN}

Sarolangun merupakan salah satu kabupaten dalam wilayah Provinsi Jambi. Secara geografis berada pada posisi astronomi $102^{0} 03$ '39" -- $103^{0} 13^{\prime} 17^{\prime \prime}$ 'Bujur Timur dan 01053'39" -- 02 46 '24" Lintang Selatan. Batas-batas administrasi adalah a) Sebelah Utara dengan Kabupaten 


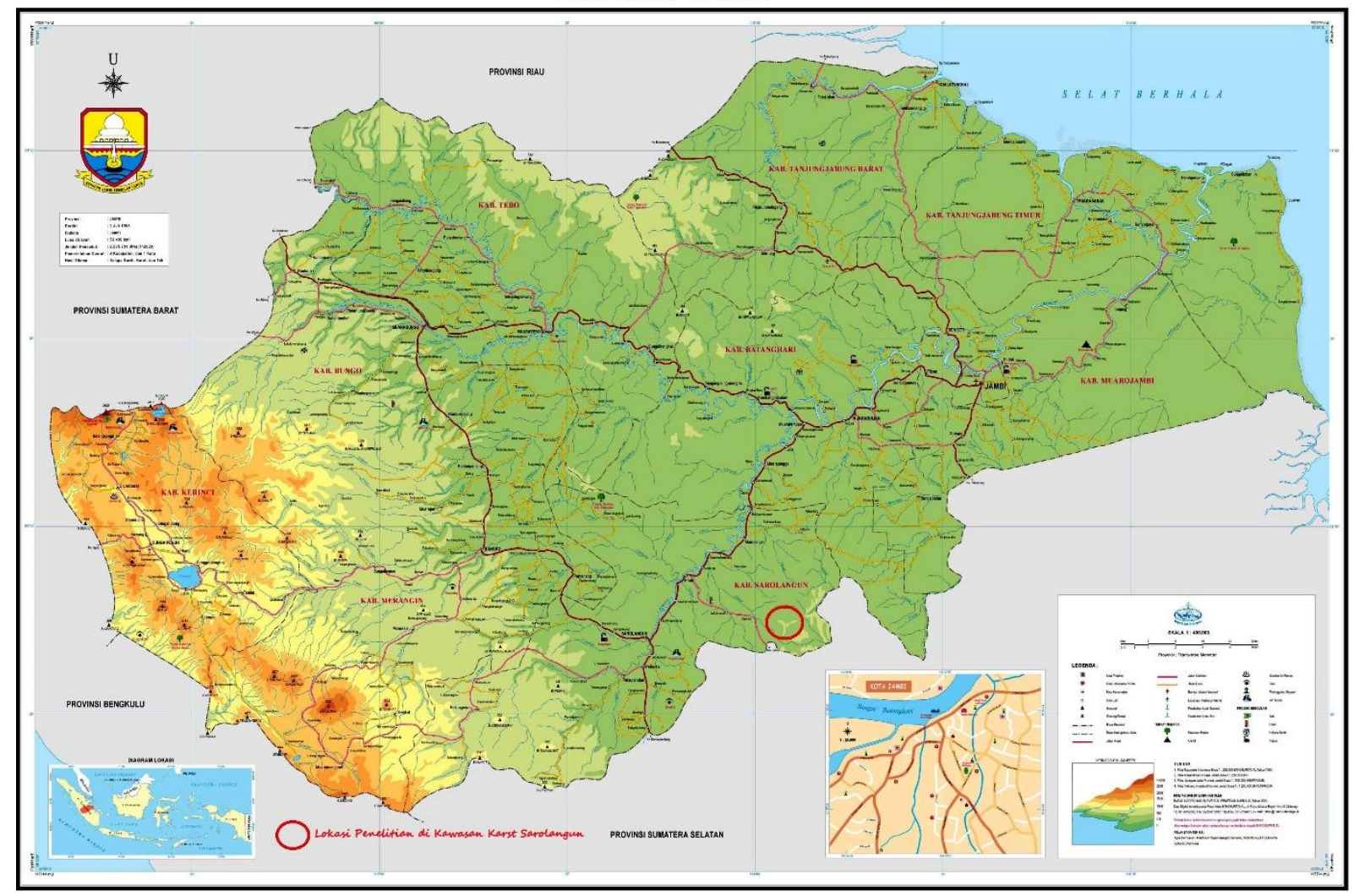

Gambar 1. Lokasi Penelitian di wilayah Kabupaten Sarolangun, Provinsi Jambi (Sumber: Dokumentasi Bakosurtanal, 2003 dengan modifikasi)

Batanghari; b) Sebelah Timur dengan Kabupaten Musi Rawas; c) Sebelah Selatan dengan Kabupaten Rejang Lebong (Provinsi Bengkulu) dan; d) Sebelah Barat dengan Kabupaten Merangin. Luas wilayahnya $6.174 \mathrm{~km}^{2}$ dan luas wilayah Kecamatan Limun $799 \mathrm{~km}^{2}$ (12,94\%). Secara administratif, Kabupaten Sarolangun terbagi ke dalam 10 Kecamatan, 9 Kelurahan, dan 149 Desa. Kecamatan Limun terdiri dari 16 Desa, dengan ketinggian 201.950 meter dari permukaan laut (dpl) (Bada Pusat Statistik, 2017).

Bentang alam Kecamatan Limun sebagai wilayah penelitian, berbentuk wilayah berbukit, dengan lereng $25-40 \%$, da luas $73.487 \mathrm{Ha}(11,90 \%)$, atau mencapai $50 \%$ dari luas keseluruhan. Bentang alam seperti ini terlihat mulai dari Dusun Bukit Melintang, Desa Napal Melintang, Desa Lubuk Bedorong, Bt. Tinjaulimun (667 m) sampai Dusun Kampung Manggis hingga ke Dusun Simpang Melako (Badan Pusat
Statistik, 2017). Kabupaten Sarolangun beriklim tropis dengan suhu rata-rata berkisar antara $23^{\circ} \mathrm{C}--32^{\circ} \mathrm{C}$, kelembaban udara rata-rata $78 \%$ dan curah hujan ratarata sebesar $260 \mathrm{~mm} / \mathrm{tahun}$. Curah hujan berkisar antara $2000-4000 \mathrm{~mm} /$ tahun. Sedangkan jumlah hari hujan rata-rata 140 270 hari/tahun. Bulan-bulan yang paling sedikit hari hujan adalah bulan Juni, Juli dan Agustus, sedangkan yang paling banyak curah hujannya yaitu pada bulan Oktober, November, Desember dan Januari dengan distribusi curah hujan cukup merata (Badan Pusat Statistik, 2017).

Menurut Fauzi et al., (2015) wilayah Sumatra yang menjadi bagian paling barat dari Kepulauan barat dari kepulauan di Indonesia masih menyimpan misteri terkait hunian gua tertua. Bukti tertua kehadiran manusia di pulau ini muncul dari koleksi fauna yang diperoleh oleh E. Dubois di situs gua Lida Ajer melalui ekskavasi tahun 1908 (Fauzi et al., 2015; Hooijer, 1948, pp. 175- 


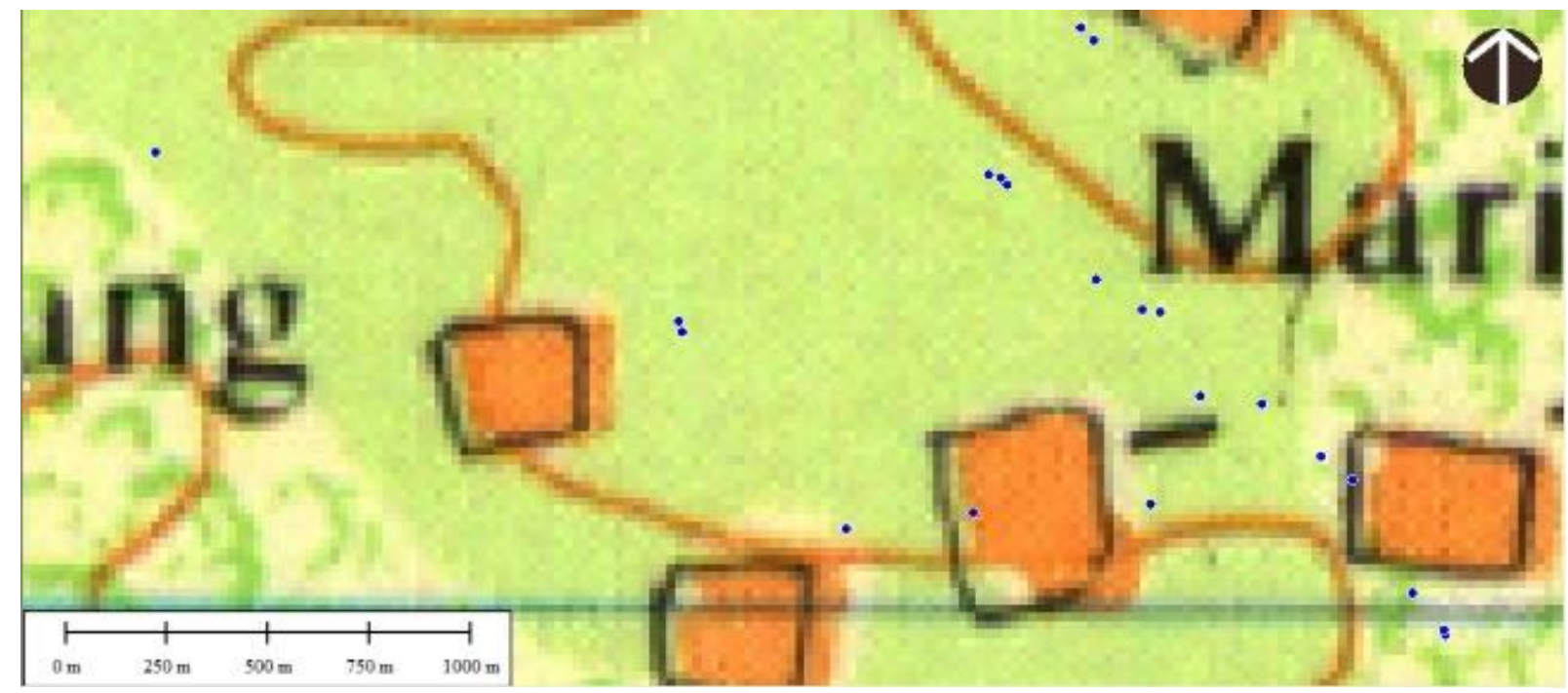

Gambar 3. Sebaran gua-gua (titik biru) di Wilayah Karst Sarolangun dalam Peta Rupa Bumi Indonesia

(Sumber: Dokumentasi Bakosurtanal, 1986 dengan modifikasi)

301; Vos, 1983). Koleksi fosil dari dataran tinggi Padang (yaitu Lida Ajer, Djambu dan Sibrambang) berumur lebih tua dari Holosen (Dubois, 1908, pp. 1235-1270). Sebuah incisor 1 dengan bagian lingual agak menembilang (semi-shoevel) serta molar kedua, diidentifikasi milik Homo sapiens. Berdasarkan pertanggalan Amino Acid Racemization (AAR) himpunan fauna dari Lida Ajer diperkirakan berasal dari 60-70 ribu tahun yang lalu (Fauzi et al., 2015; Vos, Ostende, \& Bergh, 2007, pp. 417-425). Selain itu, dinyatakan bahwa himpunan fauna tersebut menunjukkan karakter lingkungan hutan hujan tropis berdasarkan kemunculan fosil primata arboreal seperti Pongo pygmaeus, Symphalangus syndactylus dan Presbtis (Fauzi et al., 2015; Vos et al., 2007, pp. 417-425).

Bukti paling jelas adanya hunian gua prasejarah di wilayah Sumatera berasal dari situs gua Tiangko Panjang (Jambi), gua Togi Ndrawa (Nias), dan gua Pandan (Sumatra Selatan) (Bronson \& Asmar, 1975, pp. 128145; Simanjuntak, Forestier, Driwantoro, Jatmiko, \& Siregar, 2006, pp. 21-34). Pada gua-gua tersebut ditemukan sisa-sisa aktivitas manusia seperti artefak serpih dari batuan jenis obsidian dan rijang serta tulang vertebrata dengan jejak pemanfaatan seperti terbakar dan pecah segar yang intensional. Pusat Penelitian Arkeologi Nasional barubaru ini bahkan berhasil menemukan gambar cadas untuk pertama kalinya di wilayah Sumatra (Simanjuntak, Saptomo, \& Abdillah, 2009). Bukti-bukti arkeologis tersebut menunjukkan gua dan ceruk di Sumatra masih menyimpan misteri sekaligus akan potensi temuan-temuan baru yang penting peranannya dalam rekonstruksi kebudayaan nusantara, khususnya dari masa prasejarah (Fauzi et al., 2015).

Hasil penelitian penulis memberikan gambaran tentang lokasi penelitian berupa, morfologi yang khas dengan litologi yang mudah larut, dan penyaluran yang tidak teratur. Umumnya situs-situs gua mempunyai pintu yang umumnya rendah, namun ruangannya lebar dan atapnya tinggi, lorong gua panjang dan tembus di kedua sisi bukit. Wilayah penelitian yang mengalami gangguan struktur geologi, namun dampaknya terhadap situs-situs gua, dari segi ketinggian dari muka airlaut tidak mengalami perubahan, sama seperti pada saat batugamping tersebut muncul ke permukaan bumi. Namun akibat pergerakan batugamping ini, menyebabkan sebagian besar pintu-pintu gua tersebut menjadi runtuh atau tertutup oleh blok-blok 
batugamping, tetapi ruang gua tetap luas atau lebar.

Batasan masalah dalam penelitian ini, mengkaji lingkup Karst Sarolangun. Rumusan masalah dalam penelitian ini adalah: a) bagaimana kondisi bentang alam daerah telitian (satuan geomorfik, pola dan stadia sungai); b) bagaimana stratigrafi daerah telitian (kontak antar satuan batuan) dan; c) bagaimana permasalahan struktur geologi daerah telitian (struktur geologi apa saja yang mengontrol daerah telitian). Maksud dari penelitian ini adalah untuk melakukan pemetaan geologi permukaan secara umum sebagai salah satu upaya untuk menyajikan informasi geologi berdasarkan analisa pada daerah penelitian. Tujuannya adalah untuk mengetahui kondisi geologi yang meliputi aspek geomorfologi, stratigrafi, struktur geologi, dan sumber bahan alat-alat litik. Lokasi Penelitian tercantum pada Peta Rupa Bumi Indonesia Lembar 0913 Sarolangun, Edisi 1-1986 berskala 1:250.000.

\section{METODE PENELITIAN}

Metode penelitian yang digunakan adalah Kajian Pustaka, dengan mempelajari lokasi penelitian dari peneliti terdahulu, melalui buku, jurnal, maupun dari internet; survei, dengan mengamati keadaan geomorfologinya yang mencakup bentuk bentang alam, dan bentuk sungai. Selanjutnya analisis litologi yang mencakup jenis batuan, batas penyebaran batuan, dan urut-urutan pengendapan. Selama survei akan dilakukan pengambilan sampel batuan yang akan dianalisis secara laboratoris, dan pembuatan peta (peta geologi, peta geomorfologi). Langkah analisis akan disesuaikan dengan kebutuhan dan urutan kerja geologi, yaitu:

- Lithologi, sampel batuan di analisis, melalui petrologi, unsur batuan yang di analisis adalah jenis batuan, warna, kandungan mineral, tekstur, struktur, fragmen, matriks, semen. Hasil analisis diharapkan akan memberikan informasi mengenai jenis batuan (batuan beku, batuan sedimen dan batuan metamorf) dan nama batuan (andesit, batugamping, sekis dan lain sebagainya).

- Geomorfologi, penentuan bentuk bentang alam akan mempergunakan Sistem Desaunettes (Todd, 1980), yang didasarkan atas besarnya kemiringan lereng dan beda tinggi relief suatu tempat. Hasilnya adalah pembagian wilayah berdasarkan ketinggian dalam bentuk prosentase lereng. Pengamatan sungai dilakukan untuk melihat pola pengeringan (drainage basin), misalnya klasifikasi berdasarkan atas kuantitas air, pola dan stadia sungai.

- Struktur Geologi, pengamatan struktur geologi di lapangan akan dilanjutkan melalui analisis jenis struktur, misalnya patahan (fault) apakah jenis patahan normal (normal fault), patahan naik (thrust fault), patahan geser (strike fault) dan sebagainya. Lipatan (fold) apakah sinklin ataukah antiklin. Kekar (joint) apakah kekar tiang (columnar joint) atau kekar lembar (sheet joint).

Data dari kajian pustaka dengan hasil lapangan dan laboratorium dikompilasikan dengan hasil penelitian penulis, sebagai bahan interpretasi peta geologi dan peta topografi.

\section{HASIL DAN PEMBAHASAN \\ 1. Geologi Wilayah Sarolangun}

Penelitian tektonostratigrafi di bagian selatan Pulau Sumatera menunjukkan adanya kompleks melange tektonik dari bongkah batuan metamorfisme dan batuan beku berupa kompleks batuan acak yang terpengaruh oleh tektonisasi pada Akhir Kapur. Sedangkan batuan pratersier di Sumatera bagian selatan boleh dikatakan hingga sekarang belum cukup banyak diketahui, jika dibandingkan dengan endapan tersier yang kaya akan minyak bumi (Sartono, 1988, pp. 1-24).

Wilayah Sarolangun dibentuk oleh morfologi bukit-bukit berbentuk kerucut 
dengan relief sedang, kemiringan lereng kurang lebih $36^{\circ}$, ketinggiannya berkisar $270-330$ m di atas muka laut. Karakteristik bentuk bentang alam kerucut ini sangat khas dan mudah dikenal, baik di lapangan maupun pada potret udara. Sebagian besar batugamping di daerah ini telah mengalami karstifikasi, terutama batugamping yang terletak di bagian barat sedangkan batugamping di bagian timur karsifikasi eksokarsnya terdapat di bagian tengah. Secara regional batugamping kompleks Bukit Bulan termasuk Anggota Mersip Dari Formasi Peneta (Suwarna et al., 1992). Anggota Mersip tersusun oleh batugamping malihan dengan sisipan serpih gampingan. Batugamping setempat sebagai marmer, kelabu hingga kelabu muda, terkekarkan kuat sehingga mengaburkan pelapisan asal, mengandung koral. Urat halus kuarsa dan kalsit sejajar perdaunan. Serpih gampingan, kelabu kecoklatan, terdapat tufan dan atau karbonan, terkekarkan kuat dengan urat-urat halus sejajar perdaunan. Tebal formasi Ini kurang lebih $300 \mathrm{~m}$, diendapkan pada lingkungan laut dangkal dengan kemiringan $70^{\circ}-80^{\circ}$ arah barat daya. Lokasi tipe di
Kampung Mersip yang berumur Yura Akhir sampai Kapur Awal. Struktur geologi yang berkembang pada batugamping berupa sesar naik dengan arah baratlaut-tenggara (Oktariadi \& Tarwedi, 2011, pp. 1-19).

Geologi wilayah Karst Sarolangun, yang akan diuraikan adalah tentang kondisi geologi dan aspek-aspek geologi lainnya (bentang alam, stratigrafi, dan struktur geologi), yang erat kaitannya dengan keberadaan situs-situs di wilayah tersebut dan sekitarnya. Uraian tentang kondisi geologinya mencakup bentang alam, stratigrafi, dan struktur geologi adalah sebagai berikut:

\section{a. Geomorfologi}

Morfologi atau bentuk bentang alam dipengaruhi oleh beberapa faktor yaitu: $a$ ) Lithologi; b) Struktur geologi; c) Stadia daerah dan; d) Tingkat perkembangan erosi (Thornbury, 1964). Berdasarkan hal tersebut diatas, maka secara umum bentang alam (morfologi) di wilayah Sarolangun pada pengamatan lapangan, memperlihatkan kondisi dataran bergelombang. Kondisi bentang alam seperti ini, apabila di

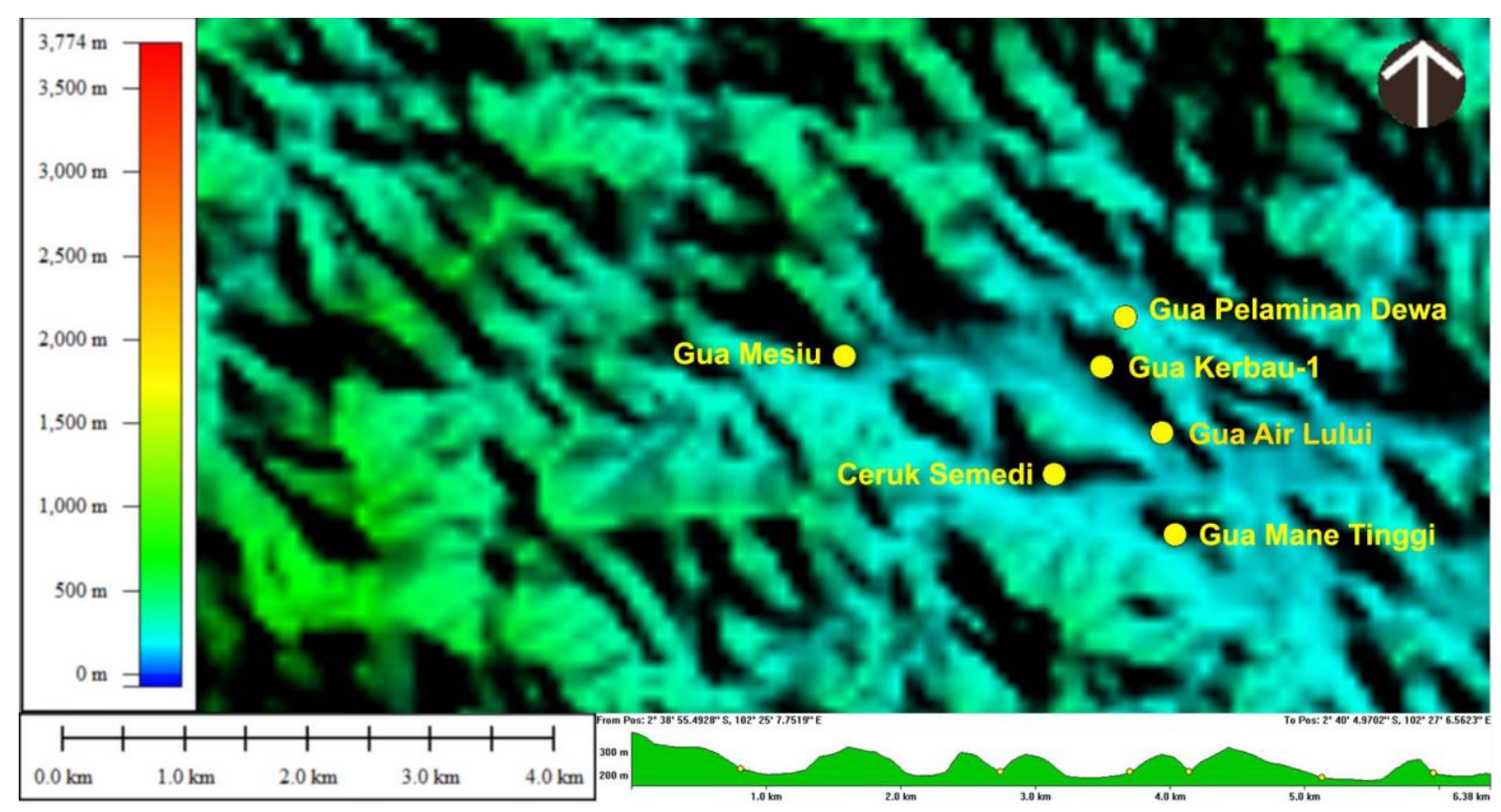

Gambar 4. Bentang alam situs gua di Karst Sarolangun

(Sumber: Dokumentasi Jarvis et al., 2008, dengan modifikasi) 
klasifikasikan dengan mempergunakan Sistem Desaunettes (Desaunetes, 1977; Todd, 1980), yang berdasarkan atas besarnya prosentase kemiringan lereng dan beda tinggi relief suatu tempat, maka wilayah penelitian terbagi atas empat satuan morfologi yaitu:

Satuan Morfologi Dataran, dicirikan dengan bentuk permukaan yang sangat landai dan datar, dengan prosentase kemiringan lereng antara 0\%-2\%. Satuan morfologi dataran, pada umumnya ditempati oleh penduduk sebagai wilayah pemukiman, dan pertanian.

Satuan Morfologi Bergelombang Lemah, dicirikan dengan bentuk bukit yang landai, relief halus, lembah yang melebar dan menyerupai huruf "U", bentuk bukit yang agak membulat dengan prosentase kemiringan lereng antara 2\%-8\%. Satuan morfologi bergelombang lemah, pada umumnya berupa hutan yang ditumbuhi oleh pohon-pohon besar, dan semak belukar.

Satuan Morfologi Bergelombang Kuat, dicirikan dengan lereng yang terjal, bentuk relief masih agak kasar dengan prosentase kemiringan lereng antara 8\%$16 \%$. Satuan morfologi ini pada umumnya merupakan hutan belukar dan pada beberapa tempat dimanfaatkan sebagai lahan perkebunan kelapa sawit.

Satuan Morfologi Karst, tersusun oleh batugamping, dengan kenampakan khas seperti bentuk bukit bulat dengan lereng tegak, dolena, pipa karst, stalaktit dan stalagmit, travertin, sungai bawah tanah, voclus, ponore, gua-gua sisi lereng dan guagua kaki bukit (clift foot cave). Ketinggian wilayah penelitian dan sekitarnya, secara umum adalah 100 - 500 meter diatas permukaan air laut.

Pola pengeringan permukaan (surface drainage pattern) di Wilayah Sarolangun berarah aliran ke selatan-utara, dan utara-selatan menuju ke Sungai Batang Tembesi, mengikuti bentuk bentang alam lokasi penelitian. Sungai induk adalah Sungai Limun (berhulu Bukit Lepesuh 822 meter), Sungai Kulur (berhulu Bukit Rasa 849 meter), dan Sungai Batang Asai (berhulu Bukit Bukok 778 meter), sedangkan anak-anak sungainya adalah Sungai Rebah, Sungai Anak Singkut, Sungai Melinau, Sungai Merendang dan beberapa sungai kecil lainnya yang tak bernama.

Sungai induk dan anak sungai termasuk pada kelompok sungai yang berstadia Sungai Dewasa-Tua (old-mature river stadium), dan Stadia Sungai Tua (old river stadium) (Lobeck, 1939; Thornbury, 1964). Berpola pengeringan Dendritik, dan Pola Pengeringan Rectangular (Lobeck, 1939; Thornbury, 1964). Berdasarkan klasifikasi atas kuantitas air, maka sebagian dari sungai-sungai tersebut, termasuk pada Sungai Periodik/Permanen. Sedangkan sungai-sungai lainnya termasuk pada Sungai Episodik/Intermittent (Lobeck, 1939; Thornbury, 1964).

\section{b. Stratigrafi}

Wilayah Sarolangun tersusun oleh batuan tertua adalah Formasi Peneta berumur Jura-Kapur, dan batuan termuda adalah Aluvium yang berumur Holosen. Secara umum batuan-batuan tersebut dapat disebutkan sebagai berikut.

Aluvial, Aluvial terdiri dari pasir, lanau, dan lempung serta merupakan hasil pelapukan batuan penyusun wilayah penelitian. Satuan batuan ini terhampar di satuan morfologi dataran dan di sepanjang sungai-sungai induk di wilayah penelitian. Aluvial berumur Holosen (Suwarna et al., 1992).

Batu Gamping, berdasarkan klasifikasi petrologi, batugamping (limestone) di lokasi penelitian, termasuk jenis batuan sedimen yang berwarna segar putih, kelabu dan kecoklatan, dan lapuk berwarna coklat putih kekuningan. Batugamping ini termasuk pada Batuan Sedimen Kimia dan Batuan Sedimen Non Klastik serta tersusun atas kalsium Karbonat $\mathrm{CaCO}_{3}$ (Huang, 1962). Batu gamping teramati dengan baik di seluruh gua-gua yang diteliti di Desa Limun atau di Karst Sarolangun (Intan, 2015).Penentuan 


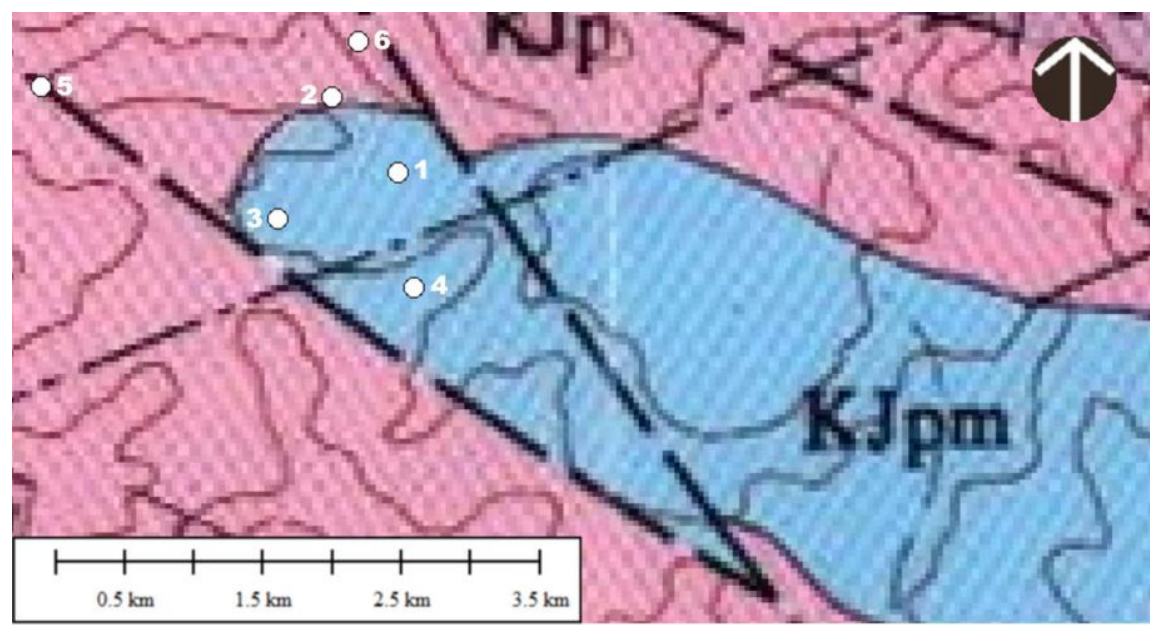

\section{KETERANGAN}

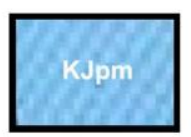

1. Anggota Mersip Formasi Peneta

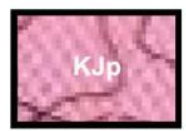

2. Formasi Peneta
1. Gua Air Lului

2. Gua Kerbau-1

3. Ceruk Semedi

4. Gua Mane Tinggi

5. Gua Mesiu

6. Gua Pelaminan Dewa

Gambar 5. Peta geologi regional wilayah Karst Sarolangun dan sebaran situs gua (Sumber: Dokumentasi Suwarna, 1992 dengan modifikasi)

umur batugamping, dilakukan dengan cara korelasi antar batuan yang didasarkan atas ciri-ciri litologi, kondisi daerah dan persebaran batuan serta memenuhi Prinsip Stratigrafi Indonesia. Berdasarkan hal tersebut, maka batugamping dapat disebandingkan dengan Anggota Mersip Formasi Peneta yang terdiri dari batugamping kelabu muda-tua kristalin. Atas dasar kesebandingan batuan, maka batugamping di Karst Sarolangung berumur Jura-Kapur (Suwarna et al., 1992).

Batu Lanau, berdasarkan klasifikasi petrologi, batulanau (siltstone) di lokasi penelitian, termasuk jenis batuan sedimen yang berwarna segar putih keabu-abuan dan lapuk berwarna coklat keabu-abuan serta bertekstur klastik (lutit), dan berstruktur berlapis (stratified) (perlapisan sejajar). Berukuran butir (grainsize) 1/256 - 1/128 $\mathrm{mm}$ (very fine silt-fine silt) dan sortasi (sorting) butiran termasuk dalam sortasi sedang hingga baik, dengan bentuk butiran subrounded-rounded. Komposisi mineral adalah kuarsa, dan feldspar. Berdasarkan atas genesanya batulanau ini termasuk pada kelompok Batuan Sedimen Mekanik (epyclastic) (Huang, 1962).

Batulanau teramati dengan baik di Dusun Sungai Beduri (Desa Maribung), Desa Napal Melintang, dan di Sungai Ketari Besar (Dusun Napal Melintang) (Intan, 2015). Penentuan umur batulanau, dilakukan dengan cara korelasi antar batuan yang didasarkan atas ciri-ciri litologi, kondisi daerah dan persebaran batuan serta memenuhi Prinsip Stratigrafi Indonesia. Berdasarkan hal tersebut, maka batulanau dapat disebandingkan dengan Formasi Peneta (Suwarna et al., 1992) yang terdiri dari batusabak, serpih, batulanau dan batupasir, sisipan batugamping, mengandung fosil Clodocoropsisi mirabilis. Atas dasar kesebandingan batuan, maka batulanau berumur Jura-Kapur.

\section{c. Struktur Geologi}

Wilayah Sarolangun secara regional, merupakan suatu wilayah dari Sesar Besar 


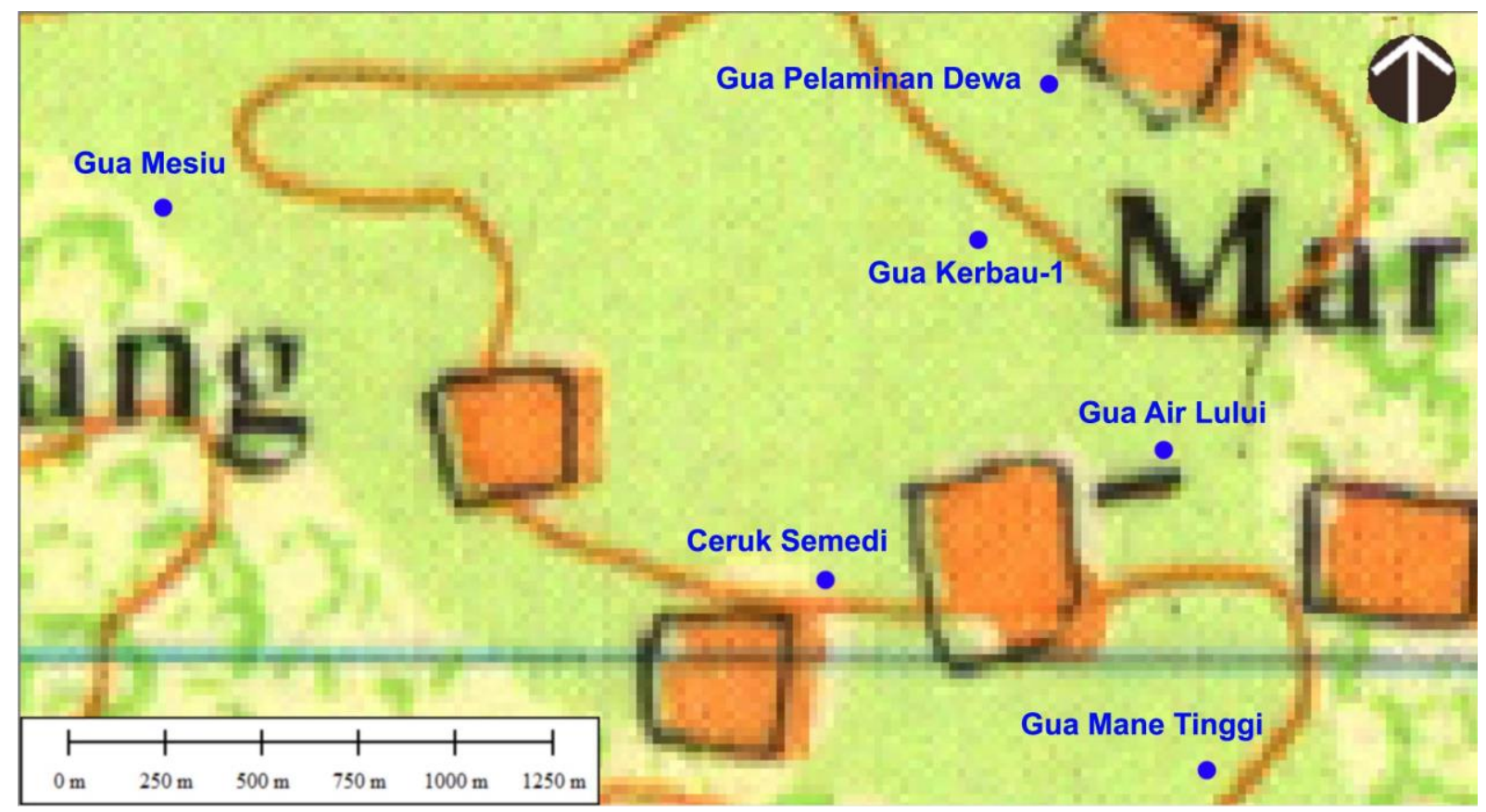

Gambar 6. Sebaran Situs Gua di Wilayah Kabupaten Sarolangun dalam Peta Rupa Bumi Indonesia

(Sumber: Dokumentasi Bakosurtanal, 1986 dengan modifikasi)

Sumatera. Kegiatan tektonik di daerah ini menghasilkan struktur-struktur geologi seperti Sesar. Sesar/patahan (fault) yang melalui daerah penelitian termasuk pada jenis Sesar Geser (strike fault) (Billing, 1972), dengan indikasi primer berupa Cermin Sesar (slickenside) yang teramati di Bukit Bulan,

Struktur geologi yang melintasi wilayah Sarolangun dan sekitarnya yang dapat diidentifikasi adalah

- Sesar geser (strike fault), berarah barat laut - tenggara, yang teramati di wilayah Mersip, Maribung, Muara Kutu, Sungai Batang Asai, Bukit Tekalakanin, Dusun Bukit, Lubuk Mas dan Sungai Beduri.

- Sesar geser (strike fault) berarah, timur timurlaut - barat baratdaya, terlihat di wilayah Bukit Bukok, Sungai Beduri, Maribung, Napal Melintang, dan Dusun Bukit.

\section{Situs Gua Karts Sarolangun}

Survei di Kabupaten Sarolangun dilakukan terhadap "Situs Tertutup" atau gua-gua yang mempunyai indikasi hunian masa lalu. Di Asia Tenggara, kehidupan di gua (cave) atau ceruk (rock shelter) mencapai puncaknya pada Kala Holosen (Nurani, 2005, pp. 1-10). Survei di Kabupaten Sarolangung dilaksanakan di Kecamatan Limun, dan Tim Penelitian telah berhasil mendata 22 lokasi Situs Tertutup (gua). Adapun hasil survei yang telah dilaksanakan di wilayah Karst Sarolangun adalah sebagai berikut:

\section{a. Gua Air Lului}

Gua Air Lului merupakan tipe gua kaki bukit yang termasuk wilayah Dusun Dalam, Desa Napal Melintang, Kecamatan Limun, Kabupaten Sarolangun, Provinsi Jambi. Gua Air Lului terletak pada $2^{\circ} 39^{\prime} 30,5^{\prime}$, Lintang Selatan dan $102^{\circ} 26^{\prime} 51,7^{\prime}$ ' Bujur Timur, dengan ketinggian 194 meter diatas permukaan airlaut, dengan arah hadap $\mathrm{N} 220^{\circ} \mathrm{E}$ (Barat daya) (Intan, 2015).

Adanya pilar membuat Gua Air Lului mempunyai 3 pintu. Pintu-1 berukuran lebar mulut gua 3,7 meter, tinggi mulut gua 4,5 meter, dan panjang kedalam 6,6 meter. Pintu-2 berukuran lebar mulut gua 1,7 meter, 
tinggi mulut gua 2,6 meter, dan panjang kedalam 7,4 meter. Pintu-3 berukuran lebar mulut gua 1,9 meter, tinggi mulut gua 2,5 meter, dan panjang kedalam 6,3 meter. Ukuran ruang gua panjang 8,2 meter, lebar 7,3 meter, dan tinggi 6,6 meter. Di dalam gua mengalir sungai bawah tanah dengan arah barat-timur. Sirkulasi udara dan intensitas sinar termasuk sedang-baik. PH dan kelembaban $6,4 / 40 \%$, dengan ornamen berupa stalaktit, stalagmit, pilar, dan batu alir (flowstone), kemiringan lantai (dip) $3^{\circ}$. Di depan Gua Air Lului dengan jarak 2 meter mengalir Sungai Ketari (Intan, 2015).

Dari hasil pengamatan, gua ini memenuhi persyaratan untuk disebut sebagai gua hunian masa lalu, serta ditemukannya gambar cadas, namun tidak berhasil menemukan artefak dan non artefak (Intan, 2015).

\section{b. Gua Kerbau}

Gua Kerbau-1 merupakan tipe gua kaki bukit yang termasuk wilayah Dusun Dalam, Desa Napal Melintang, Kecamatan Limun, Kabupaten Sarolangun, Provinsi Jambi. Gua Kerbau-1 terletak pada $2^{\circ} 39^{\prime} 12,9^{\prime \prime} \quad$ Lintang Selatan dan $102^{\circ} 26^{\prime} 36,2^{\prime \prime}$ Bujur Timur, dengan ketinggian 220 meter diatas permukaan airlaut, dengan arah hadap N240 E (Barat baratdaya) (Intan, 2015).

Pintu Gua Kerbau-1 berukuran lebar 11,4 meter, dan tinggi 4,2 meter. Ruang gua berukuran lebar 2,8 meter, tinggi 1,6 meter, dan panjang 6,2 meter. Gua ini mempunyai dua lorong, lorong pertama berarah hadap $\mathrm{N} 20^{\circ} \mathrm{E}$, dan lorong kedua berarah hadap $\mathrm{N} 70^{\circ}$ E. Sirkulasi udara dan intensitas sinar termasuk baik, $\mathrm{pH}$ dan kelembaban 6,5/40\%, dengan ornamen berupa stalaktit, stalagmit, dan pilar, serta kemiringan lantai (dip) $3^{\circ}($ Intan, 2015)

Gua Kerbau-1 terdapat lukisan gua, yang oleh tim peneliti memberi nama Galeri Wahyu, tinggi lukisan gua bervariasi dari 1 meter hingga 4 meter dari lantai gua. Dari hasil pengamatan, gua ini memenuhi persyaratan untuk disebut sebagai gua hunian masa lalu, serta ditemukannya artefak dan non artefak, berupa alat-alat litik dari batuan andesit, bongkah getah damar, dan fragmen tulang, serta gambar cadas (Intan, 2015)

\section{c. Ceruk Semedi}

Ceruk Semedi merupakan tipe gua tebing yang termasuk wilayah Dusun Napal Melintang, Desa Napal Melintang, Kecamatan Limun, Kabupaten Sarolangun, Provinsi Jambi. Ceruk Semedi terletak pada 2'39'41,4" Lintang Selatan dan $102^{\circ} 26^{\prime} 23,4$ " Bujur Timur, dengan ketinggian 222 meter diatas permukaan airlaut. dengan arah hadap N200 ${ }^{\circ}$ E (Selatan baratdaya) serta kemiringan lereng (dip) $25^{\circ}$. Ceruk Semedi berukuran lebar 14,4 meter, tinggi 13,2 meter, dan panjang kedalam 5,9 meter. Sirkulasi udara dan intensitas sinar termasuk baik, $\mathrm{pH}$ dan kelembaban 6,5/40\%, dengan ornamen berupa stalagmit, kemiringan lantai (dip) $5^{\circ}$. Tinggi gua dari dataran adalah 20 meter. Dari hasil pengamatan, gua ini memenuhi persyaratan untuk disebut sebagai gua hunian masa lalu, ditunjang dengan pengamatan permukaan yang dilakukan secara sepintas serta pengaisan di beberapa bagian mulut gua ditemukan adanya indikasi tinggalan artefak berupa alat-alat litik (obsidian, chert, alat penggerus atau mortar dari batu andesit), fragmen tembikar (berhias), dan fragmen moluska (Intan, 2015).

\section{d. Gua Mene Tinggi}

Gua Mane Tinggi merupakan tipe gua kaki bukit yang termasuk wilayah Dusun Dalam, Desa Napal Melintang, Kecamatan Limun, Kabupaten Sarolangun, Provinsi Jambi. Gua Mane Tinggi terletak pada $2^{\circ} 39^{\prime} 57,3^{\prime \prime}$ Lintang Selatan dan $102^{\circ} 26^{\prime} 55,3$ ' Bujur Timur, dengan ketinggian 215 meter diatas permukaan airlaut, dengan arah hadap $\mathrm{N} 185^{\circ} \mathrm{E}$ (Selatan).

Ruang Gua Mane Tinggi berukuran 
lebar 51,3 meter, tinggi 2,8 meter, dan ukuran panjang kedalam 8,8 meter. Sirkulasi udara dan intensitas sinar termasuk baik. PH dan kelembaban $6,5 / 50 \%$, dengan ornamen berupa stalaktit, dan stalagmit, kemiringan lantai (dip) $10^{\circ}$. Tepat di depan Gua Mane Tinggi terdapat Sungai Mane Tinggi dengan lebar 6 meter (Intan, 2015).

Dari hasil pengamatan, gua ini memenuhi persyaratan untuk disebut sebagai gua hunian masa lalu, ditunjang dengan pengamatan permukaan yang dilakukan secara sepintas serta pengaisan di beberapa bagian mulut gua ditemukan adanya indikasi tinggalan artefak berupa alat-alat litik, berupa serpih dari batuan basal, dan jasper (Intan, 2015).

\section{e. Gua Mesiu}

Gua Mesiu merupakan tipe gua tebing yang termasuk wilayah Dusun Napal Melintang, Desa Napal Melintang, Kecamatan Limun, Kabupaten Sarolangun, Provinsi Jambi. Gua Mesiu terletak pada 2०39'10,2” Lintang Selatan dan $102^{\circ} 25^{\prime} 28,1^{\prime \prime}$ Bujur Timur, dengan ketinggian 254 meter diatas permukaan airlaut. Gua Mesiu mempunyai dua buah pintu yaitu pintu-1 berarah hadap $\mathrm{N} 225^{\circ} \mathrm{E}$ (Barat daya), pintu-2 berarah hadap $\mathrm{N} 180^{\circ} \mathrm{E}$ (Selatan). Gua Mesiu mempunyai kemiringan lereng (dip) $47^{\circ}$.

Pintu-1 Gua Mesiu berukuran lebar 9,2 meter,dan tinggi 6,5 meter, dengan ukuran ruang panjang 10,1 meter, lebar 17,3 meter, dan tinggi 9,1 meter. Pintu-2 Gua Mesiu berukuran lebar 10,3 meter, dan tinggi 4,3 meter, dengan ukuran ruang panjang 20 meter, tinggi 23,1 meter, dan lebar 13,8 meter. Sirkulasi udara dan intensitas sinar termasuk baik. PH dan kelembaban $6,5 / 60 \%$, dengan ornamen berupa stalaktit, stalagmit, pilar, dan batu alir (flowstone), kemiringan lantai (dip) $3^{\circ}$. Di dalam Gua Mesiu terdapat sungai bawah tanah. Tinggi Gua Mesiu dari dataran adalah 25 meter.
Dari hasil pengamatan, gua ini memenuhi persyaratan untuk disebut sebagai gua hunian masa lalu, ditunjang dengan pengamatan permukaan yang dilakukan secara sepintas serta pengaisan di beberapa bagian mulut gua ditemukan adanya indikasi tinggalan artefak berupa alat-alat litik (obsidian, chert, jasper), fragmen tembikar, dan fragmen moluska (Intan, 2015).

\section{f. Gua Pelaminan Dewa}

Gua Pelaminan Dewa merupakan tipe gua tebing yang termasuk wilayah Dusun Sungai Beduri, Desa Maribung, Kecamatan Limun, Kabupaten Sarolangun, Provinsi Jambi. Gua Pelaminan Dewa terletak pada $2^{\circ} 38^{\prime} 59,99^{\prime}$ Lintang Selatan dan $102^{\circ} 26^{\prime} 42,2^{\prime \prime}$ Bujur Timur, dengan ketinggian 224 meter diatas permukaan airlaut. dengan arah hadap $\mathrm{N} 30^{\circ} \mathrm{E}$ (Utara timurlaut) serta kemiringan lereng (dip) 27.

Gua Pelaminan Dewa berukuran berukuran lebar mulut gua 11,2 meter, tinggi mulut gua 5 meter. Ukuran ruang gua lebar 7,5 meter, panjang 10,3 meter, dan tinggi 4,9 meter. Sirkulasi udara dan intensitas sinar termasuk baik. $\mathrm{PH}$ dan kelembaban $6,5 / 60 \%$, dengan ornamen berupa stalaktit, stalagmit, pilar, batu alir (flowstone), kemiringan lantai (dip) $10^{\circ}$. Tinggi gua dari dataran adalah 12 meter.

Dari hasil pengamatan, gua ini memenuhi persyaratan untuk disebut sebagai gua hunian masa lalu, ditunjang dengan pengamatan permukaan yang dilakukan secara sepintas serta pengaisan di beberapa bagian mulut gua ditemukan adanya indikasi tinggalan artefak berupa fragmen tembikar (tepian, badan), fragmen tulang, dan fragmen moluska (Intan, 2015).

\section{g. Lokasi Survei Lainnya}

Lokasi gua lainnya di wilayah Karst Sarolangun, yang dikunjungi selama survei berjumlah 16 lokasi yang tersebar di wilayah Desa Napal Melintang (Dusun Dalam, Dusun Napal Melintang Desa Maribung 

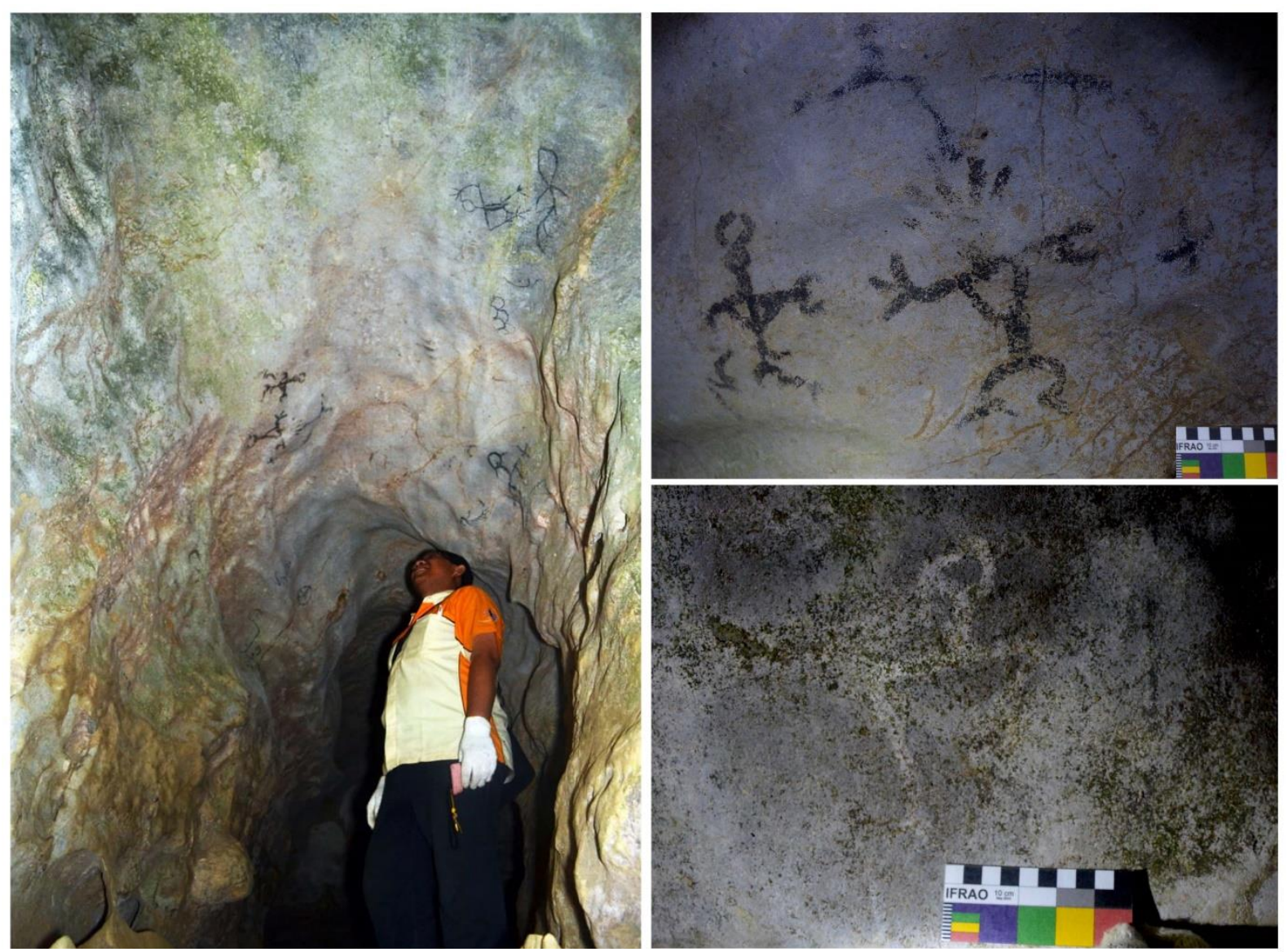

Gambar 7. Lokasi gambar cadas di salah satu lorong di Gua Sungai Lului (kiri), gambar cadas berwarna hitam (kanan atas), gambar cadas berwarna putih (kanan bawah)

(Sumber: Dokumentasi Balar Sumsel, 2015)

(Dusun Sungai Beduri, dan Dusun Tinggi). Meskipun kondisi lokasi dinilai layak untuk dihuni, namun tidak terdapat temuan yang mengindikasikan adanya aktivitas manusia masa lalu. Adapun lokasi yang dikunjungi adalah: Gua Colo Petak (No.7), Gua Hendra1 (No.8), Gua Hendra-2 (No.9), Ceruk Siti Agak-1 (No.10), Gua Hendra-3 (No.11), Ceruk Siti Agak-2 (No.12), Gua Bapak Kica (No.13), Gua Kerbau-2 (No. 14), Gua Kerbau-3 (No.15), Gua Parit (No.16), Gua Acis (No.17), Gua Lubuk Karib (No.18), Gua Asmadi (No.19), Gua Kandang-1 (No.20), Gua Kandang-2 (No.21), dan Gua Colo Petak (No.22) (lihat lampiran tabel).

\section{Gambar Cadas}

Gua dengan gambar cadas, pertama kali ditemukan pada tahun 2009 di Gua Harimau (Desa Padang Bindu, Kecamatan Semidang Aji, Kabupaten Ogan
Komering Ulu, Sumatera Selatan), oleh Tim Pusat Penelitian Arkeologi Nasional. Penemuan gua dengan gambar cadas sangat mengesankan, karena selama ini tinggalan sejenis belum pernah ditemukan di Sumatra dan Jawa. Penemuan ini jelas meruntuhkan teori para ahli, bahwa seni cadas tidak mencapai Sumatera dan Jawa, tetapi lebih tersebar di Indonesia Timur dan wilayah lainnya. Posisi kronologi seni cadas ini memang belum diketahui, namun jika dibandingkan dengan seni cadas serupa di wilayah Indonesia Timur, bukan tidak mungkin merupakan bagian dari budaya preneolitik yang berkembang pada paruh pertama Holosen (Simanjuntak et al., 2009).

Gua dengan gambar cadas yang ditemukan tahun 2015 di Karst Sarolangun, merupakan penemuan yang kedua di Sumatera, yaitu di Gua Air Lului dan Gua Kerbau-1. 

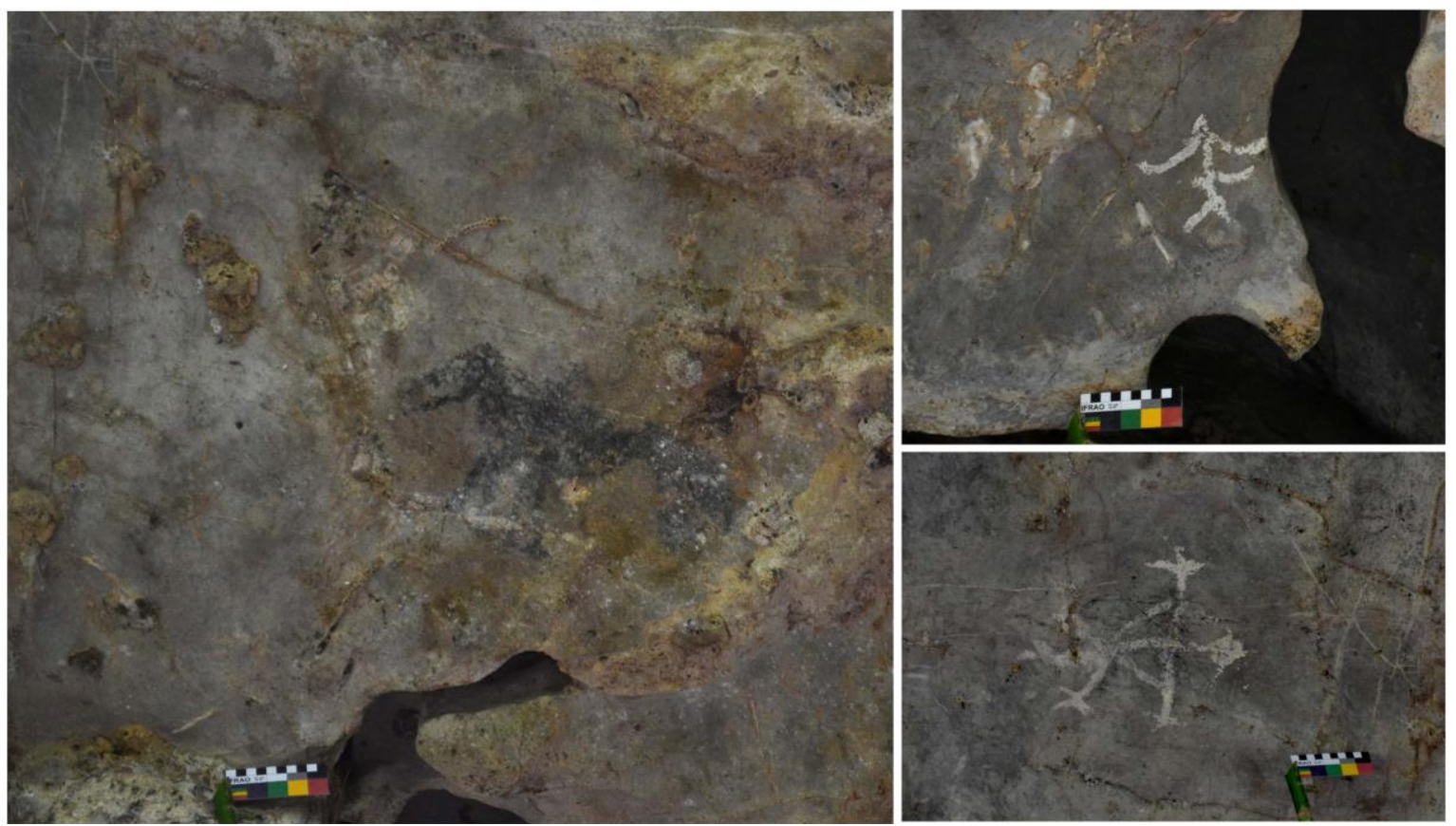

Gambar 8. Gambar cadas berwarna hitam di Gua Kerbau-1 (kiri),

gambar cadas berwarna putih (kanan atas), gambar cadas berwarna putih (kanan bawah)

(Sumber: Dokumentasi Balar Sumsel, 2015)

Gambar cadas di Gua Sungai Lului terdiri atas 23 gambar berwarna hitam dan 1 gambar berwarna putih. Gambar cadas dengan figur antropomorfik, binatang (?), dan motif geometris, terletak di dinding gua dengan ketinggian 0,9-2 meter di atas permukaan lantai gua, pada sebuah lorong masuk gua yang penuh lukisan (Fauzi et al., 2015). Gambar cadas berwarna hitam didominasi oleh oleh gambar garis-garis dinamis, figur antropomorfik, reptil, hewan melata, sarang lebah, serta bentuk geometrik (lingkaran, bujur sangkar dan persegi panjang) yang tidak (Fauzi, 2016).

Gambar cadas di Gua Kerbau-1 terdiri atas 1 gambar berwarna hitam dan 9 lainnya yang berwarna putih. Gambargambar tersebut terletak di langit-langit gua dengan ketinggian 4 meter meter diatas permukaan lantai gua, berupa gambar berwarna hitam menyerupai figur binatang yang ditunggangi oleh manusia, yang diwarnai secara penuh (block) tanpa ada ruang kosong di tengahnya. Selain itu, terdapat gambar bermotif antropomorfik dan geometris yang menggunakan pigmen putih
(Fauzi et al., 2015). Terdapat cerita yang dituangkan dalam gambar sebagai bahasa rupa. Hal ini tidak terlepas dari adanya interaksi dari kondisi lingkungan, mewujudkan kehidupan yang bisa terjaga, lestari dengan bahasa tanda simbolik (Mas'ud, 2015).

\section{Klasifikasi Petrologi Alat Litik}

Salah satu hasil industri pendukung budaya gua-gua Karst Sarolangun, adalah alat-alat litik. Alat-alat litik yang ditemukan tersebut, berdasarkan atas hasil klasifikasi petrologi, ternyata mereka memilih batuanbatuan yang mempunyai sifat-sifat khusus antara lain, struktur batuan yang kompak (massive), sifat mudah terbelah (breakability) yang baik, tidak mempunyai pecahan (fracture), mempunyai kekerasan (hardness) yang tinggi, kesamaan mineral (homogenity), dan beberapa sifat fisik lain yang mendukung (Intan, 2004, pp. 153256).

Klasifikasi petrologi dilakukan terhadap semua alat-alat litik yang ditemukan selama penelitian, yang bertujuan 


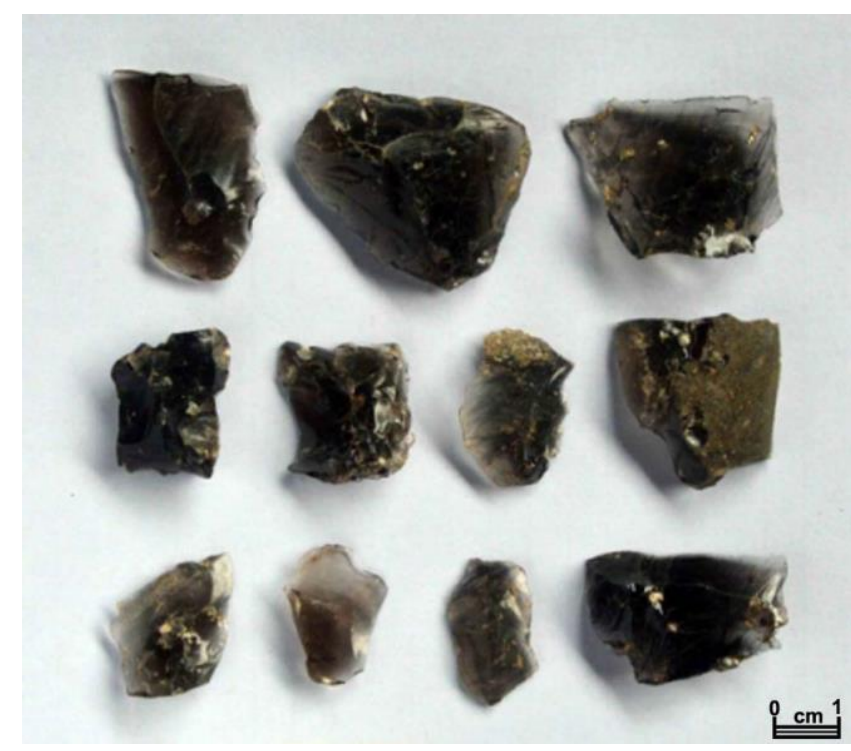

Gambar 9. Obsidian yang ditemukan di Gua Mesiu (Sumber: Dokumentasi Balar Sumsel, 2015)

untuk mengetahui jenis batuan yang dimanfaatkan sebagai alat-alat litik. Hasil klasifikasi tersebut, maka batuan yang terpilih sebagai alat-alat litik adalah jasper, chert, basal, andesit, dan obsidin, sebagai berikut:

- Jasper, berdasarkan klasifikasi petrologi, jasper termasuk batuan sedimen yang memberikan kenampakan warna segar coklat, merah, hitam dan lapuk berwarna merah kehitaman. Bertekstur non klastik, dengan struktur tidak berlapis (non stratified). Komposisi mineral adalah hematit. Berdasarkan atas genesanya, maka jasper termasuk pada batuan sedimen kimia (Huang, 1962).

- Chert, berdasarkan klasifikasi petrologi, chert termasuk batuan sedimen yang memberikan kenampakan warna segar putih kuning keabu-abuan dan lapuk berwarna abu-abu pudar kehitaman. Bertekstur non klastik, dengan struktur tidak berlapis (non stratified). Komposisi mineral adalah silikat atau opal. Berdasarkan atas genesanya, maka chert termasuk pada batuan sedimen kimia (Huang, 1962).

- Basal, berdasarkan klasifikasi petrologi, basal termasuk batuan beku yang memberikan kenampakan warna segar hitam kelam dan lapuk berwarna hitam keabu-abuan. Bertekstur kristalinitas holohyalin, tekstur granularitas afanitik, tektur fabrik (bentuk kristal) subhedralanhedral, dan relasi hypidiomorphicallotriomorphic. Berstruktur kompak (massive) hingga kekar (joint), dengan komposisi mineral utama kuarsa, plagioklas, olivin, piroksen, hornblende, biotit, dan komposisi mineral tambahan apatit, iron ore, spinel, rutil, zircon, khromit dan mafic mineral. Klasifikasi berdasarkan tempat terbentuknya termasuk pada batuan beku lelehan (vulcanic rocks), sedangkan klasifikasi berdasarkan sifat kimia dan komposisi mineralnya termasuk pada batuan beku basa (Huang, 1962).

- Andesit, berdasarkan klasifikasi petrologi, andesit termasuk batuan beku yang memberikan kenampakan warna segar abu-abu muda dan lapuk berwarna hitam keabu-abuan. Bertekstur hipokristalin, afanitik-porfiroafanitik, subhedral-anhedral, hypidiomorphicallotriomorphic. Berstruktur kompak (massive). Komposisi mineral utama adalah kuarsa, plagioklas, hornblende, 


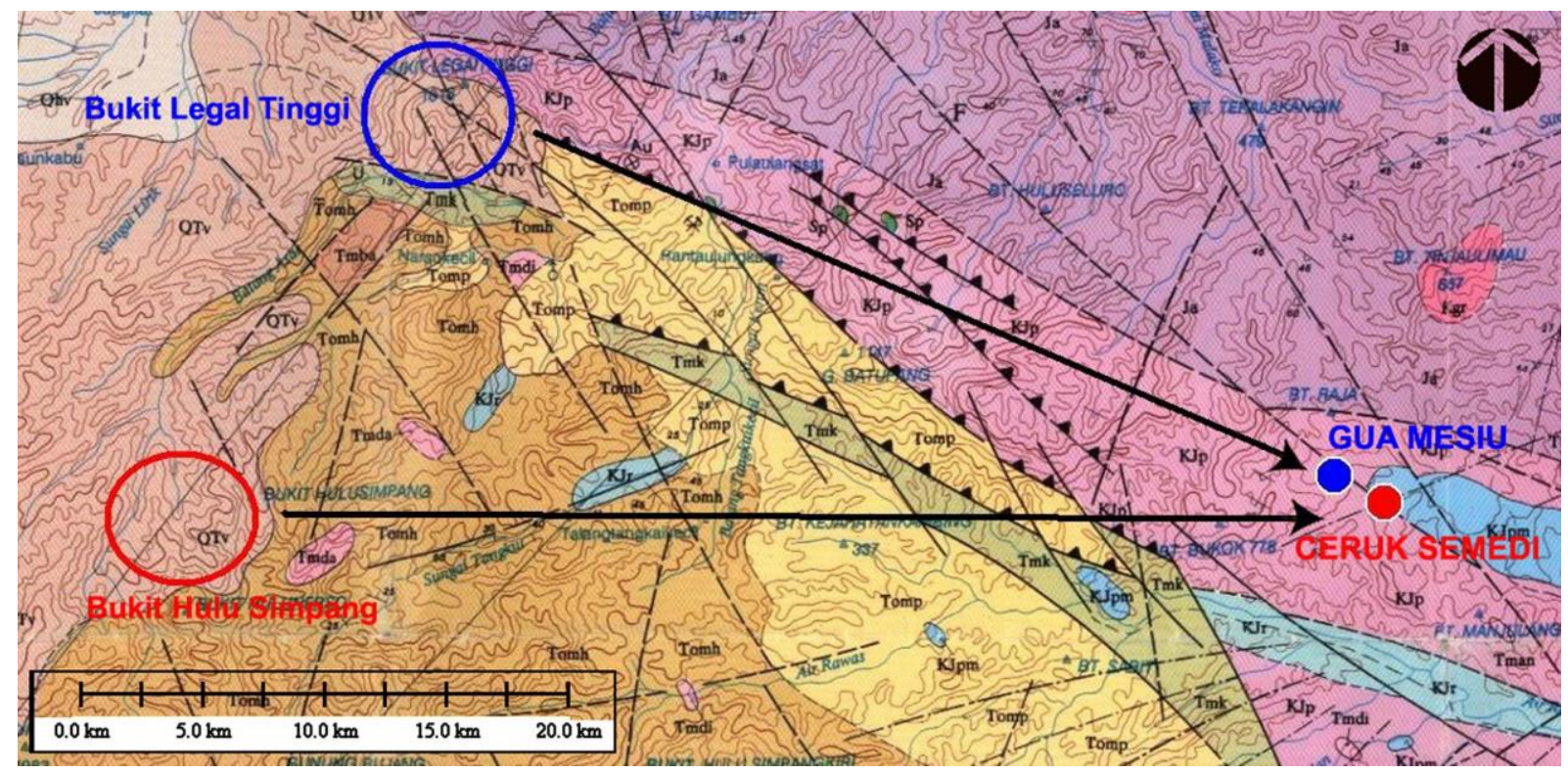

Gambar 10. Gua Mesiu dan Ceruk Semedi dan Lokasi obsidian di Wilayah Sarolangun dalam Peta Geologi

(Sumber: Dokumentasi Suwarna, 1992 dengan modifikasi)

biotit, dan piroksen. Sedangkan mineral tambahan adalah apatite, zircon, sphene, dan iron ore (Huang, 1962).

- Obsidian, berdasarkan klasifikasi petrologi adalah, obsidian termasuk batuan beku, berwarna segar hitam mengkilat dan lapuk berwarna hitam. Berstruktur kompak (massive), dengan tekstur holohialin, gelas silika. Berat jenisnya 3,36-2,5 $\mathrm{gram} / \mathrm{cm}^{3}$, dengan kekerasan 5-5,5 Skala Mohs. Berdasarkan klasifikasi tempat terbentuknya termasuk dalam batuan beku lelehan (volkanic rocks) yaitu magma yang membeku secara tiba-tiba dipermukaan bumi. Berdasarkan klasifikasi atas dasar sifat kimia dan komposisi mineral, termasuk pada batuan beku asam yaitu mengandung silikat lebih besar dari $60 \%$, kaya akan unsur alkali dan miskin terhadap kalsium/kapur dan mineral ferromagnesian, umumnya berwarna muda atau terang. Obsidian terbentuk dari magma yang bersifat rhyolitis, dasitis, mengandung air kurang dari $1 \%$, bila kandungan airnya kira-kira 10\% maka disebut pitchstone (Huang, 1962).
Alat-alat litik dari obsidian yang hanya ditemukan di Gua Mesiu dan Ceruk Semedi, sedangkan di gua-gua lainnya tidak ditemukan. Lokasi sumber obsidian di wilayah Sarolangun, ditemukan di sebelah barat dan barat laut dari situs-situs gua tersebut. Lokasi obsidian yang dekat dari situs-situs adalah Bukit Hulu Simpang dan Bukit Legal Tinggi. Jarak terjauh dari situs ke lokasi obsidian adalah $40 \mathrm{~km}$ (garis lurus) dan jarak terdekat adalah $33 \mathrm{~km}$ (garis lurus).

\section{Bentang Alam Karts Salorangun}

Kawasan kars adalah kawasan yang terdiri dari bentangalam yang secara khusus terjadi pada batuan karbonat (batugamping dan dolomit) yang disebabkan oleh proses karstifikasi. Formasi batuan kawasan karst memiliki ciri morfologis yang berada di bawah permukaan bumi (endokars) maupun yang berada di permukaan (eksokars). Bentukan morfologis endokarst dan eksokarst kawasan karst antara lain adalah bukit-bukit kerucut, lereng-lereng nyaris tegak (tower karst), danau, mata air, loronglorong sungai bawah tanah, luweng (dolina), dan gua-gua (Nasruddin, 2016, pp. 1-16). 
Bentang alam Karst Sarolangun, morfologinya termasuk dalam satuan morfologi karst tersusun oleh batugamping dengan bentuk permukaan yang kasar, serta kenampakan khas seperti bentuk bukit bulat dengan lereng tegak, dolena, pipa kras, stalaktit dan stalagmit, travertin, sungai bawah tanah, voclus, ponore, gua-gua sisi lereng dan gua-gua kaki bukit (clift foot cave). Pembentukan bentang alam ini berkaitan dengan bidang retakan (sesar/patahan) yang arahnya berkedudukan tegak atau hampir tegak. Tinggi menara antara 100-300 meter, berlereng terjal dan datar pada puncaknya. Di antara bukit-bukit tersebut terdapat lembah sempit yang datar, serta berbentuk memanjang.

Bentuk bentang alam karst Sarolangun adalah suatu topografi yang terbentuk pada daerah dengan litologi berupa batuan yang mudah larut, menunjukkan relief yang khas, penyaluran tidak teratur, aliran sungai secara tiba-tiba masuk ke dalam tanah dan meninggalkan lembah kering dan muncul kembali di tempat lain sebagai mata air yang besar.

\section{Batu Gamping dan Gua}

Batugamping (limestone) penyusun gua-gua di Wilayah Karst Sarolangun termasuk dalam Anggota Mersip Formasi Peneta, yaitu batugamping kelabu muda-tua kristalin umur Jura-Kapur. Sedangkan Formasi batuan induknya termasuk pada Formasi Peneta yang terdiri dari batusabak, serpih, batulanau dan batupasir, sisipan batugamping, mengandung fosil Clodocoropsisi mirabilis umur Jura-Kapur (Suwarna et al., 1992).

Gua-Gua di Wilayah Sarolangun, beberapa pintu gua umumnya rendah, namun ruangannya lebar dan atapnya tinggi, lorong gua panjang dan tembus di kedua sisi bukit, tampak depan dari beberapa gua yang lebar, umumnya ada sungai bawah tanah baik yang berair maupun yang dalam kondisi kering. Suatu gua akan terbentuk setelah batuan karbonat mengalami proses consolidasi kemudian dilanjutkan ke proses lithifikasi yang disertai dengan sementasi (Pettijohn, 1975). Atau dengan kata lain, gua-gua hanya dapat dibentuk dari batuan yang terlitifikasi, dan jelas bahwa karakter sedimen awal dan sejarah diagenetik adalah faktor-faktor yang mengontrol lokasi sebuah gua. Proses kelahiran sebuah gua biasa disebut dengan speleogenesis, dan fitur dari geologi sangat besar pengaruhnya di sini.

\section{Pengaruh Struktur Geologi}

Struktur geologi yang bekerja di wilayah penelitian Sarolangun dan sekitarnya, dalam pengamatan lapangan ditemukan adanya patahan atau sesar (fault) dari jenis sesar geser (strike fault) (Billing, 1972).

Di Wilayah Sarolangun struktur geologi berupa sesar geser (strike fault) membagi dua batuan dari Formasi Peneta dan Anggota Mersip Formasi Peneta. Sesar geser (strike fault) ini berarah relatif barat laut-tenggara. Batugamping tempat keletakan gua-gua tersebut termasuk pada Anggota Mersip Formasi Peneta.

Sesar geser (strike fault) ini membuat blok barat dari batugamping bergerak mendatar ke arah barat laut. Blok yang bergerak inilah ditemukan banyak gua-gua hunian masa prasejarah. Dampak dari sesar geser (strike fault) terhadap keletakan guagua yang diteliti dari segi ketinggian dari muka airlaut tidak mengalami perubahan, sama seperti pada saat batugamping tersebut muncul ke permukaan bumi. Namun akibat pergerakan batugamping ini, menyebabkan sebagian besar pintu-pintu gua tersebut menjadi runtuh atau tertutup oleh blok-blok batugamping, tetapi ruang gua tetap luas atau lebar.

\section{Ancaman Karts Sarolangun}

Kawasan Karst Sarolangun, selain memiliki tinggalan kepurbakalaan yang sangat potensial (situs gua-gua prasejarah), ternyata juga menyimpan sumber daya mineral (potensi tambang) yang sangat 
melimpah, misalnya batugamping, batuan beku dan lempung. Salah satu potensi tambang yang melimpah tersebut, adalah batugamping yang termasuk dalam Kelompok Bahan Galian Golongan "C". Menurut data dari Badan Pusat Statistik Kab. Sarolangun. Jambi, singkapan batugamping, terbanyak ditemukan di daerah Napal Melintang Kecamatan Limun dengan Kadar $\mathrm{CaO}(54,86-55,85 \%)$ dan cadangan diperkirakan sebesar 57,8 juta (Sarolangun Dalam Angka, 2017).

\section{Di Kabupaten Sarolangun, khususnya masyarakat di Kecamatan} Limun, diresahkan tentang rencana penghancuran pegunungan kapur di wilayah Karst Sarolangun, yang memiliki potensi tambang untuk dikelola menjadi sumber bahan baku semen. Berita ini tentunya menjadi berita duka bagi fihak kepurbakalaan, karena dibalik itu terdapat malapetaka yang akan turut memusnahkan sejumlah tinggalan masa lalu yang tersimpan didalam gua-gua pada ratusan bahkan ribuan tahun silam. Olehnya itu, instansi yang berwenang terhadap tinggalan kepurbakalaan di wilayah Karst Sarolangun, seharusnya keberatan apabila investor melakukan kegiatan penambangan di dalam wilayah situs arkeologi.

\section{Adaptasi Lingkungan}

Bentang alam Karst Sarolangun di kontrol oleh gejala struktur, sehingga masyarakat pendukung situs tersebut, memanfaatkan konsep adaptasi. Eriawati (1999), menyatakan bahwa manusia dalam beradaptasi saling terkait dengan lingkungan. Keterkaitan itu sifatnya dinamis sehingga manusia secara terus menerus memodifikasi perilakunya yang terpilih agar dapat menjawab setiap tantangan yang ada, sehingga dapat menyesuaikan diri (adaptif) terhadap lingkungannya. Salah satu pilihan yang paling tepat untuk menjawab tantangan lingkungan itu adalah kemampuan teknologinya. Dengan teknologi manusia mampu bukan hanya menyesuaikan tetapi memodifikasi lingkungan sesuai dengan kebutuhan yang diperlukan. Berbagai proses yang memungkinkan manusia bertahan (survive) terhadap tantangan kondisi lingkungan membuktikan kemampuan manusia untuk beradaptasi (Eriawati, 1999), sedangkan Saptomo (2008) menyatakan bahwa manusia membutuhkan sejumlah kebutuhan dasar untuk bertahan hidup. Oleh karena itu pemilihan lokasi untuk bertempat tinggal menjadi salah satu pertimbangan pokok yang selalu diperhatikan. Umumnya mereka memilih lokasi yang memiliki sumberdaya lingkungan yang melimpah, lokasi yang nyaman dan aman (Eriawati, 1999).

\section{PENUTUP}

Kehidupan manusia masa prasejarah khususnya kala Plestosen akhir sampai awal Holosen, dalam mempertahankan hidupnya masih sangat bergantung pada ketersediaan lingkungan alam sekitarnya. Seiring dengan tingkat kecerdasan dan teknologi yang dikenalnya, manusia saat itu lebih mampu mempertahankan hidupnya dan mengeksploitasi alam daripada masa sebelumnya yang masih mengembara. Hal tersebut ditunjukkan dalam pola hidup mereka untuk bertempat tinggal yang lebih menetap dengan memanfaatkan gua atau ceruk sebagai tempat tinggal mereka. Di Asia Tenggara, kehidupan di gua (cave) atau ceruk (rock shelter) mencapai puncaknya pada Kala Holosen.

Secara umum bentang alam (morfologi) di wilayah Sarolangun terbagi atas empat satuan morfologi yaitu, Satuan morfologi dataran, Satuan morfologi bergelombang lemah, Satuan morfologi bergelombang kuat, dan Satuan morfologi karst. Ketinggian wilayah penelitian dan sekitarnya, secara umum adalah $100-500$ meter di atas permukaan airlaut. Sungaisungai besar dan kecil di Wilayah Sarolangun termasuk pada kelompok sungai yang berstadia Sungai Dewasa-Tua (old- 
mature river stadium), dan Stadia Sungai Tua (old river stadium). Berpola pengeringan Dendritik, dan Pola Pengeringan Rectangular, serta termasuk Sungai Periodik/Permanen, dan Sungai Episodik/Intermittent. Batuan penyusun Wilayah Sarolangun dan sekitarnya adalah, Aluvial (berumur Holosen), Batuan Terobosan (berumur Miosen Tengah), Granit Arai (berumur Kapur Akhir- Paleosen Awal), Anggota Mersip Formasi Peneta (berumur Jura-Kapur), Formasi Peneta (berumur Jura-Kapur), dan Formasi Asai (berumur Jura). Struktur geologi yang melintasi wilayah Sarolangun dan sekitarnya yang dapat diidentifikasi adalah Sesar geser (strike fault).

Survei di Kabupaten Sarolangun, berhasil mendata 22 lokasi yang termasuk dalam wilayah Kecamatan Limun, namun ada 6 lokasi gua yang dapat disebut sebagai gua hunian masa lalu, dengan ditemukan adanya indikasi tinggalan artefak dan non artefak. Batuan yang dimanfaatkan sebagai alat-alat litik adalah jasper, chert, basal dan andesit. Batuan-batuan tersebut banyak ditemukan di sekitar lokasi penelitian, baik dalam bentuk singkapan maupun boulder. Lokasi sumber obsidian di wilayah Sarolangun, ditemukan di sebelah barat dan barat laut dari situs-situs gua tersebut. Lokasi obsidian yang dekat dari situs-situs adalah Bukit Hulu Simpang dan Bukit Legal Tinggi. Jarak terjauh dari situs ke lokasi obsidian adalah $40 \mathrm{~km}$ (garis lurus) dan jarak terdekat adalah $33 \mathrm{~km}$ (garis lurus). Bentang alam Karst Sarolangun di kontrol oleh gejala struktur, sehingga masyarakat pendukung situs tersebut, memanfaatkan konsep adaptasi.

\section{Ucapan Terima Kasih}

Terima kasih kepada Bapak M. Ruly Fauzi M.Sc. (Ketua Tim Penelitian Survei Arkeologis Potensi Gua Di Provinsi Jambi Tahap II) yang telah memberikan izin untuk mempublikasikan tulisan ini

\section{DAFTAR PUSTAKA}

Badan Pusat Statistik. (2017). Sarolangun Dalam Angka. Jambi: Badan Pusat Statistik Kab. Sarolangung.

Billing, M. P. (1972). Structural Geology. In New jersey. New Jersey: Inc. Englewood.

Bronson, B., \& Asmar, T. (1975). Prehistoric Investigation at Tiangko Panjang Cave, Sumatra. Asian Perspectives, 18(2), 128-145.

Desaunetes, J. R. (1977). Catalogue of Landforms for Indonesia": Examples of a Physiographic Approach to Land Evaluation for Agricultural Development. Bogor: Trust Fund of the Government of Indonesia Food and Agriculture Organization.

Desaunettes, J. R. (1977). Catalogue of landforms for Indonesia : examples of a physiographic approach to land evaluation for agricultural development (unpublished). Bogor: Trust Fund of the Government of Indonesia Food and Agriculture Organization.

Dubois, E. (1908). Das geologische alter der Kendeng-oder Trinil-Fauna. Aardijkskundig Genot: Tijdschr. Van Het K. Ned.

Eriawati, Y. J. (1999). Adaptasi Penghuni Gua Prasejarah Leang Burung, Kabupaten Maros, Provinsi Sulawesi Selatan. Universitas Indonesia.

Fauzi, M. R. (2016). Beberapa Hasil Awal Penelitian Arkeologi Di Kawasan Kars Bukit Bulan, Sarolangun. Siddhayatra Jurnal Arkeologi, 21(1), 1-12.

Fauzi, M. R., Prasetyo, E. S., Andhifani, R. W., Ade, A. O. H. O., \& Intan, M. F. S. (2015). Laporan Penelitian Arkeologi: Survei Arkeologis Potensi Gua Di Provinsi Jambi 
(Tahap II). Palembang.

Hooijer, D. A. (1948). Prehistoric teeth of man and of the orang utan from central Sumatra, with notes on the fossil orang utan from Java and Southern China. Meded: Overgedrukt Uit Zool.

Huang, W. T. (1962). W.T. Huang. McGraw-Hill Book Company.

Intan, M. F. S. (2004). Eksploitasi Sumber Daya Batuan. In T. Simanjuntak, R. Handini, \& B. Prasetyo (Eds.), Buku Prasejarah Gunung Sewu (pp. 153-156). Ikatan Ahli Arkeologi Indonesia.

Intan, M. F. S. (2015). Laporan Penelitian Geologi Wilayah Merangin-Sarolangun, Kabupaten Merangin Dan Kabupaten Sarolangun, Provinsi Jambi. Palembang.

Lobeck, A. K. (1939). Geomorphology, An Introduction To The Study of Landscape. New York and London: Mc Graw Hill Book Company Inc.

Mas'ud, Z. (2015). Direktori Gambar Tebing Di Kawasan Situs Maimai, Kabupaten Kaimana. Jayapura.

Nasruddin. (2016). Artefak manik-manik dalam perspektif arkeologi. Jurnal Papua, 8(1), 8194.

Nurani, I. A. (2005). Pola Pemanfaatan Gua Pada Kehidupan Manusia Prasejarah di Jawa Timur. In PIA-Kongres IAAI X. Yogyakarta.

Oktariadi, O., \& Tarwedi, E. (2011). Klasifikasi kars untuk kawasan lindung dan kawasan budi daya: Studi Kasus Kars Bukit Bulan Kabupaten Sarolangun, Provinsi Jambi. Jurnal Lingkungan Dan Bencana Geologi, 2(1), 1-19.

Pettijohn, P. J. (1975). Sedimentary Rocks. New York: Harper and Brothers.

Sartono, S. (1988). Kompleks Melange di Sumatera Selatan. In Pertemuan Ilmiah Tahunan. Bandung: IAGI.

Simanjuntak, T., Forestier, H., Driwantoro, D., Jatmiko, \& Siregar, D. (2006). Daerah Kaki Gunung, Berbagai Tahap Zaman Batu. In G. Dominique (Ed.), Menyelusuri Sungai Merunut Waktu, Penelitian Arkeologi di Sumatera Selatan (pp. 21-34).

Simanjuntak, T., Saptomo, E. W., \& Abdillah, D. (2009). Penelitian Hunian Prasejarah di padang Bindu, Baturaja, Sumatera Selatan. Jakarta.

Suwarna, N., Suharsono, Gafoer, S., Amin, T. C., Kusnama, \& Hermanto, B. (1992). Peta Geologi Lembar Sarolangun, Sumatera. Bandung: Pusat Penelitian dan Pengembangan Geologi.

Thornbury, W. D. (1964). Principle of Geomorphology. New York and London: John Wiley and Sons, inc.

Todd, D. K. (1980). Groundwater Hydrology (Second Edi). New York: John Willey and Son's.

Vos, D. J. (1983). The pongo faunas from Java and Sumatra and their significance for biostratigraphical and paleo-ecological interpretations. Paleontol. Proc., 88, 417425.

Vos, D. J., Ostende, L. W. van den H., \& Bergh, G. D. Van Den. (2007). Patterns in insular evolution of mammals: a key to island palaeogeography. In R. W. (Ed.), Biogeography, Time, and Place: Distributions, Barriers, and Islands (pp. 315245). Dordrecht: Spriger. 


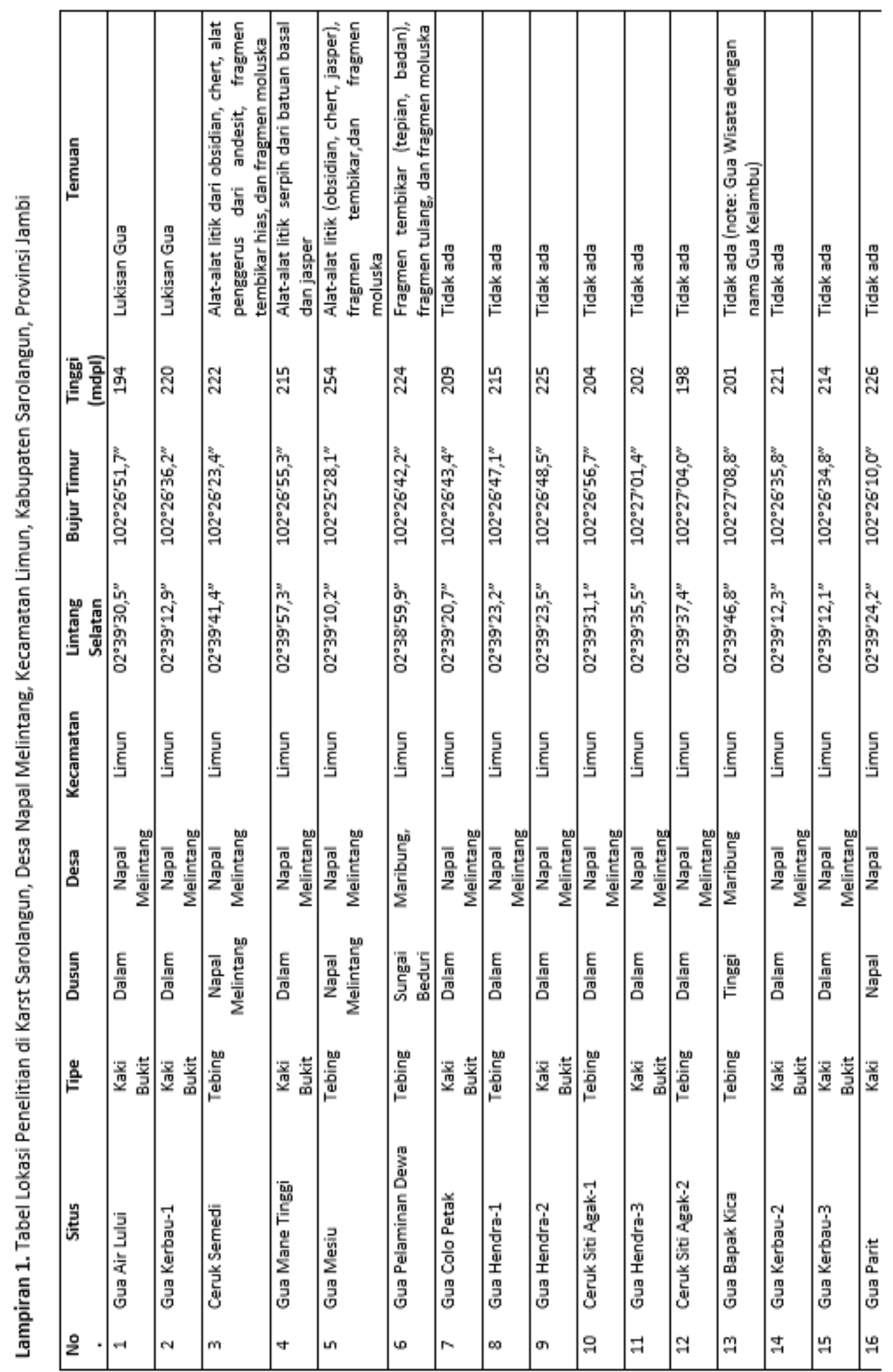

DOI: $10.2483 /$ wln.v16i1.310 


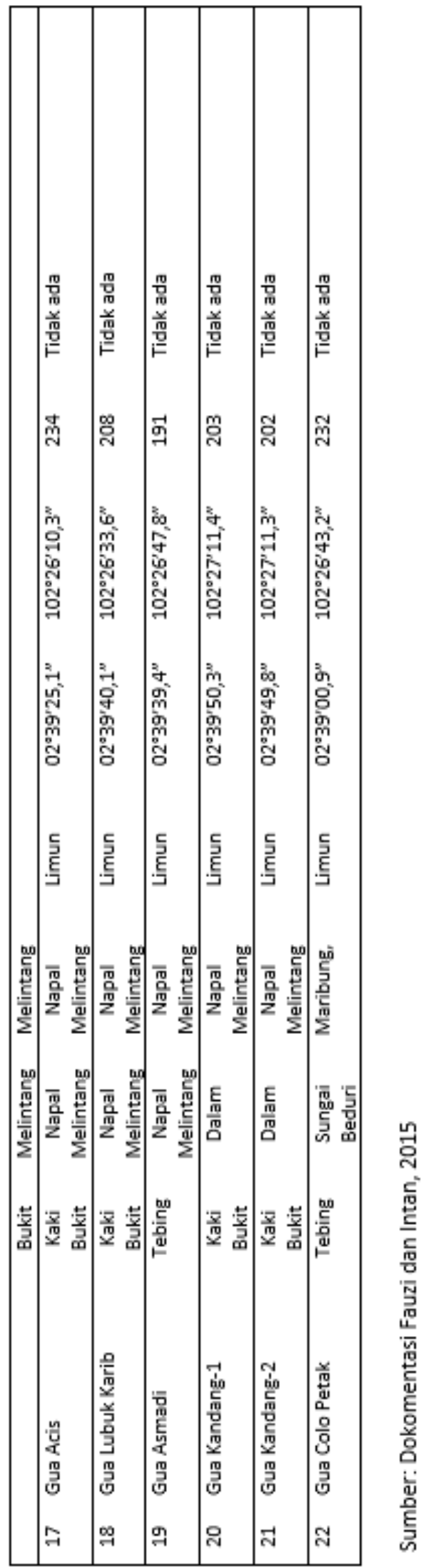

